\title{
Uforklarede synkoper
}

Synkope er et komplekst symptom med flere potentielle ætiologier. De største diagnostiske forhindringer er den periodiske og uforudsigelige karakter samt den spontane remission. Implantering af en loop recorder giver mulighed for en lang overvågnings periode og kan lette diagnostikken af synkopen.

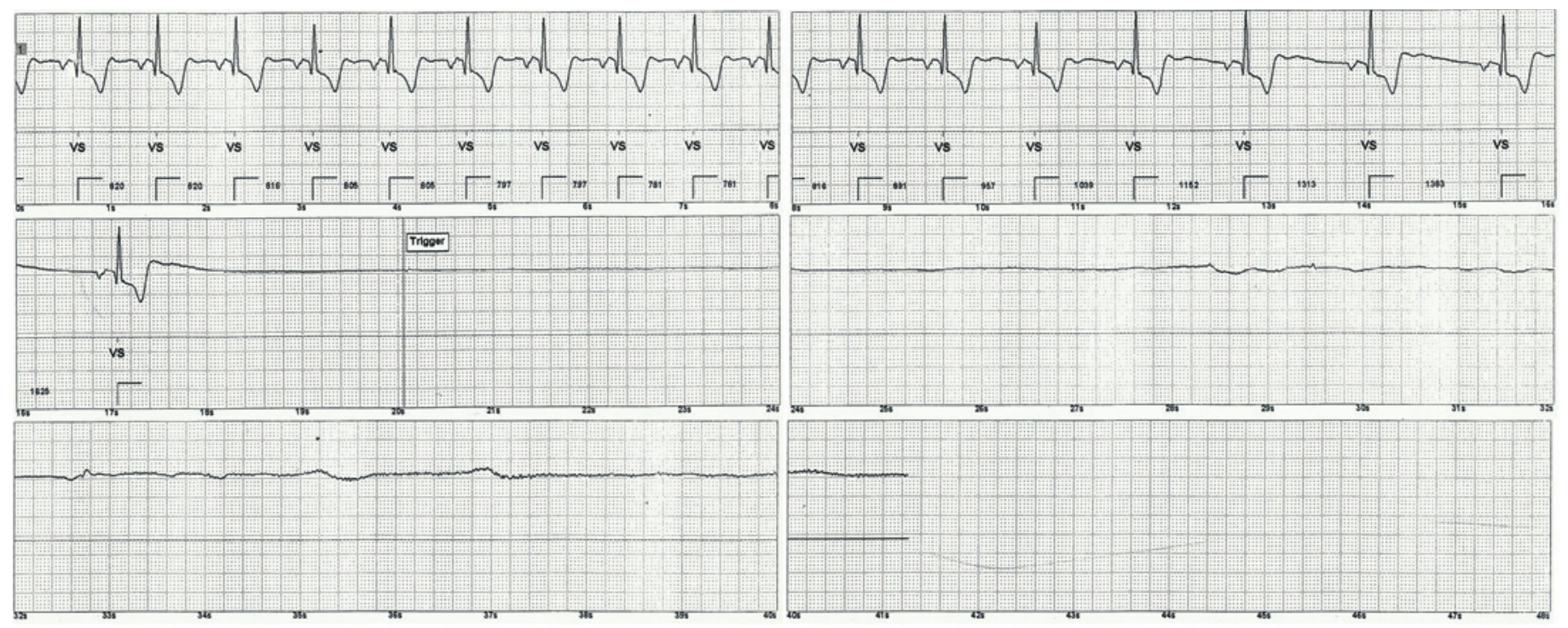

Figur tekst

Loop Recorderen med et 35 sekunders varende sinoatrialt blok

Figur 1 Aflæsning af loop recorderen viste et 35 sekunders varende sinoatrialt blok

En kvinde i starten af tresserne havde gennem tredive år haft tendens til synkope, der forekom i både hvile og ved fysisk aktivitet. Anfaldende kom cirka en gang om året, uden prodromer. Der var ingen ekskretafgang eller tungebid, patienten vågnede hurtigt op efter synkoperne og var klar og relevant. Hun var udredt i neurologisk og kardiologisk regi. Blodtrykket, biokemiske prøver, elektroencephalografi, CT af cerebrum, ekkokardiografi, Holter monitorering samt ekstern event recorder havde vist normale resultater. Man kunne ikke udelukke længerevarende asystoli eller arytmi, hvorfor man tilbød implantation af en loop recorder. Nogle måneder efter kom patienten ind efter et anfald. Loop recorderen blev udlæst og viste et 35 sekunders varende sinoatrialt blok (fig 1), hvorefter patienten straks fik en pacemaker. Siden har hun været asymptomatisk.

\section{Loop recorder}

Ved mistanke om kardial synkope er ekkokardiografi og EKG-registrering centrale undersøgelser $(1,2)$. Når der er lang tid imellem episoderne er monitoreringer som Holter og event recorder ikke hensigtsmæssige. Implanterbar loop recorder, som kom på markedet i slutningen af 1990'erne, kan være et nyttigt diagnostisk redskab til patienter med tilbagevendende synkoper af ukendt årsag (3-5). Denne implanteres subkutant i lokal anæstesi, og aktiveres af patienten eller andre under eller efter et anfald $(3,4)$. Recorderen har ligeledes hukommelse, så rytmen kan aflæses før aktivering $(3,4)$. Metoden har enkelte ulemper. Implantering indebærer kirurgi med tilhørende infektionsrisiko, og det er ikke mulig at foretage målinger som f.eks. blodtryk undervejs $(3,4)$.

Hos den aktuelle patient afslørede undersøgelsen årsagen til synkope gennem tredive år, og patienten fik adækvat behandling.

Sjældne og atypiske synkoper skal tages alvorligt og udredes. Forsinket diagnostik kan have alvorlige konsekvenser ved kardiale rytmeforstyrrelser, mens overflødige undersøgelser kan være behæftet med væsentlige omkostninger. Vi mener, at implantering af loop recorder tidligt i forløbet ved uafklaret synkope kan have såvel behandlingsmæssige som økonomiske fordele.

Patienten har givet samtykke til at artiklen bliver publiceret.

Monija Mrgan

momrg@hotmail.com

Dorte Rytter
Monija Mrgan (f. 1984) er 1. år i speciallæge uddannelsen og arbeider på Kardiologisk afdeling, Odense Universitetshospital, Danmark. Forfatter har fylt ut ICMJE-skjemaet og oppgir ingen interessekonflikter.

Dorte Rytter (f. 1976) er 1. år i speciallæge uddannelsen og arbeider på Medicinsk afdeling, Sygehus Lillebælt - Fredericia, Danmark. Forfatter har fylt ut ICMJE-skjemaet og oppgir ingen interessekonflikter.

\section{Litteratur}

1. Mehlsen J, Mehlsen AB. Udredning og behandling af reflekssynkoper. Ugeskr Læger 2008; 170 718-23.

2. Jemtrén A, Frykman V. ABC om synkope. Läkartidningen 2006; 39: 2873-5.

3. Kenny RA, Krahn AD. Implantable loop recorder: evaluation of unexplained syncope. Heart 1999; 81 : 431-3.

4. Brignole M, Menozzi C, Moya A et al. Implantable loop recorder: towards a gold standard for the diagnosis of syncope? Heart 2001; 85: 610-2.

5. Krahn AD, Klein GJ, Yee R et al. Randomized assessment of syncope trial: conventional diagnostic testing versus a prolonged monitoring strategy. Circulation 2001; 104: 46-51.

Mottatt 19.4. 2013, godkjent 29.5. 2013. Medisinsk redaktør Siri Lunde Strømme.

Publisert først på nett. 